\title{
INTERAKSI AKTOR DALAM PERUMUSAN KEBIJAKAN PENGELOLAAN PERTAMBANGAN DI KABUPATEN KOLAKA UTARA
}

\author{
Fahrul Rijal ${ }^{1}$, Muhlis Madani ${ }^{2}$, Fatmawati ${ }^{3}$ \\ ${ }^{1}$ Program Studi Ilmu Pemerintahan Fakultas Ilmu Sosial Dan Ilmu Politik \\ Universitas Muhammadyah Makassar \\ ${ }^{2}$ Program Studi Ilmu Administrasi Negara Fakultas Ilmu Sosial Dan Ilmu Politik \\ Universitas Muhammadyah Makassar \\ Jl. Sultan Alaudin No. 259 Makassar 90221 \\ Tlp. 0411-866972 ext. 107. Fax. 0411-8655888
}

\section{ABSTRACT}

This study aimed at knowing how the interaction of the actors in policy formulation. The method used was quantitative descriptive supported by qualitative data in the form of frequency tables. 20 people of population in the study would be also as the sample. Techniques of Data Collection in this research would be observation, questionnaires and developed the interviews for the respondent. The data were analyzed quantitative descriptively in which analyzing all the data collected by the authors, and then presented in the form of frequency tabulation completed by responds of the respondents obtained from informants, interviews, and questionnaires. The results showed how the interaction of actors in policy formulation mining management by the following indicators: 1. Patterns of cooperation (bargaining), The relationship between Parliament and Local Government established and done well and successfully, 2. Persuasive models (persuasion), a). An accurate negotiation precision, b). Many of them had been agreed of the approval for the local government and parliament in compromising problems occurred. The factors that influence were supporting factors and inhibiting factors. The supporting factors of the actors interaction and formulation of mining management policy in North Kolaka were: a). communication. b). Actors human resources. Factors inhibiting the interaction of actors in the formulation of management policies of mining management northern Kolaka. a). Commitment. b). Bureaucratic structure.

Keywords: interaction, policy formulation, mining management.

\section{ABSTRAK}

Penelitian ini bertujuan untuk mengetahui bagaimana interaksi aktor dalam perumusan kebijakan. Metode penelitian yang digunakan adalah deskriptif kuantitatif yang didukung dengan data kualitatif dalam bentuk tabel frekuensi. Populasi dalam penelitian sekaligus merupakan sampel sebanyak 20 orang. Data dikumpulkan dengan menggunakan teknik berupa observasi, kuesioner serta dikembangkan dengan wawancara kepada responden. Data tersebut dianalisis secara Deskriptip kuantitatif yaitu menganalisis semua data yang berhasil dikumpulkan penulis, dan selanjutnya disajikan dalam bentuk tabulasi frekuensi dilengkapi dengan tanggapan responden yang diperoleh dari hasil Informan, wawancara, dan kuesioner. Dari hasil penelitian menunjukkan bagaimana interaksi aktor dalam perumusan kebijakan pengelolaan pertambangan dengan indikator: 1. Pola kerja sama (bargaining), Hubungan yang terjalin antara DPRD dan Pemerintah Daerah terjalin baik dan berhasil dilakukan, 2. Model persuasif (persuasion), a). ketepatan negosiasi tepat, b). persetujuan pemerintah daerah dan DPRD dalam mengkompromikan permasalahan yang terjadi banyak yang setuju. Faktorfaktor yang mempengaruhi seperti faktor pendukung dan faktor penghambat. Adapun faktor pendukung interaksi aktor dam perumusan kebijakan pengelolaan pertambangan di Kabupaten Kolaka Utara ialah: a). komunikasi. b). sumber daya pelaksana. Faktor penghambat interaksi aktor dalam perumusan kebijakan pengelolaan pertambangan di kabupaten kolaka utara. a). Komitmen. b). Struktur birokrasi.

Kata kunci: interaksi, perumusan kebijakan, pengelolaan pertambangan. 


\section{A. PENDAHULUAN}

Otonomi Daerah pada hakekatnya adalah penyerahan hak, wewenang, dan kewajiban daerah untuk mengatur dan mengurus rumah tangganya sendiri sesuai dengan Peraturan Perundang-undangan. Dengan dilaksanakannya Otonomi Daerah berarti sebagian besar kewajiban Pemerintah Pusat kini telah menjadi tanggung jawab Pemerintah Daerah, tentunya dengan harapan dapat terlaksana secara lebih baik dan terfokus atau tepat sasaran. Hal tersebut sejalan dengan tuntutan pemberlakuan Otonomi Daerah yang menginginkan peranan daerah yang lebih besar dalam pelaksanaan pemerintahan dan pembangunan di daerah. Posisi Pemerintah daerah lebih dekat sehingga mengetahui kondisi masyarakat di daerahnya lebih baik dibanding Pemerintah Pusat. Dengan kewenangan Otonomi Daerah yang telah diberikan, berbagai kendala pembangunan yang selama ini ada akan bisa diatasi dengan meraih berbagai peluang guna menyejahterakan kehidupan masyarakatnya.

Undang-Undang Nomor 32 Tahun 2004 tentang Pemerintahan Daerah telah mengubah sistem pemerintahan di daerah dengan penguatan sistem desentralisasi (Otonomi Daerah). Perubahan tersebut merupakan implementasi dari Pasal 18 Ayat (2) UndangUndang Dasar Negara Republik Indonesia Tahun 1945 yang mengamanatkan bahwa "Pemerintah daerah provinsi, daerah kabupaten, dan kota mengatur dan mengurus sendiri urusan pemerintahan menurut asas otonomi dan tugas pembantuan".

Sebagai penyelenggara pemerintah daerah, pemerintah daerah dan DPRD mempunyai kewenangan untuk mengatur dan mengurus kepentingan masyarakat setempat. Dalam melaksanakan kewenangan untuk mengatur, pemerintah daerah dan DPRD perlu merumuskan kebijakan publik. Berdasarkan Undang-Undang, proses perumusan kebijakan dilakukan oleh pemerintah daerah dan DPRD. Dalam proses perumusan kebijkan publik akan terjadi interaksi antara masyarakat dengan penyelengga pemerintahan daerah dan antara institusi penyelenggara pemerintahan daerah.
Mekanisme interaksi antar aktor dalam perumusan kebijakan mempertemukan kepentingan masing-masing aktor, berlangsung sepanjang proses perumusan dan pelaksanaan kebijakan publik. Mekanisme interaksi intensif inilah yang menyebabkan peluang-peluang untuk saling mengakomodasi kepentingan masing-masing aktor menjadi lebih mudah terjadi. Faktor yang sangat penting dalam penyusunan sebuah kebijakan yaitu isu-isu apa yang layak dianggap sebagai masalah, atau bagaimana isu dirumuskan, bagaimana didefinisikan dengan baik inti dari sebuah masalah, nilai-nilai dan etika apa yang menyertai tujuan, sasaran dan cara penyelesaiannya (Madani, 2011:3).

Pembuatan sebuah kebijakan seringkali dinyatakan dengan kata atau istilah yang berbeda-beda. Proses penyusunan kebijakan merupakan satu rangkaian aktivitas yang tidak terpisahkan dari sebuah proses kebijakan, artinya suatu aktivitas yang berlasung secara simultan. Dalam proses penyusunan kebijakan terdapat proses tawar menawar (bargaining) yang terjadi antara aktor-aktor pembuat kebijakan dengan menggunakan kekuasaan dan kewenangan dilaksanakan bukan untuk menyinkronkan kepentingan rakyat namun digunakan untuk meraih kepentingan (interest) dan kekuasaan (power) itu senndiri (Madani, 2010:9). Pasal 24 ayat (1) Undang-Undang No. 32 Tahun 2004 disebutkan bahwa kepala daerah adalah pemimpin daerah. Dengan demikian, kepala daerah mempunyai kedudukan untuk memimpin daerah sebagai kesatuan masyarakat hukum, yang didalamnya terdapat pemerintah daerah dan komunitas-komunitas otonom lainnya. Dalam sistem pemerintahan daerah menurut Undang-Undang No. 32 tahun 2004, DPRD adalah unsur penye-lenggara pemerintahan daerah.

Sebagai unsur penyelenggara pemerintahan daerah, kedudukan DPRD adalah sejajar dan merupakan mitra kepala daerah, dengan fungsi masing-masing. DPRD lebih banyak menjalankan fungsi mengatur, dalam bentuk membuat kebijakan berupa peraturan daerah. Sedangkan kepala daerah lebih lebih banyak menjalankan fungsi mengurus, bentuk 
pelaksanaan kebijakan yang telah ditetapkan oleh DPRD. Pembahasan tentang kebijakan pemerintah tidak dapat dilepaskan dari peranan pemerintah itu sendiri di dalam suatu kebijakan yang dikeluarkannya. Peran pemerintah sangat penting terhadap pertumbuhan pembangunan daerah Sulawesi Tenggara utamanya Kabupaten Kolaka Utara. Salah satu permasalahan di sektor pertambangan terkhusus di Kabupaten Kolaka Utara yaitu bahwasanya terdapat penambang-penambang liar yang tidak memiliki Izin Usaha Pertambangan (IUP) yang telah menyalahi aturan perundang-undangan yang berakibat pada kerusakan lingkunagan hidup. Hal ini tidaklah terlepas dari kebijakan yang dibuat oleh Pemerintah Daerah dan DPRD Kabupaten Kolaka Utara.

Kabupaten Kolaka Utara adalah merupakan daerah baru dengan Ibukota Lasusua. Kabupaten ini merupakan hasil pemekaran dari Kabupaten Kolaka yang disahkan dengan UU Nomor 29 tahun 2003 tanggal 18 Desember 2003.

Daerah ini, memiliki posisi yang menguntungkan dalam berbagai kegiatan ekonomi, terutama pada sektor pertambangan. Dengan kondisi tersebut diharapkan mampu menjadikan Kabupaten Kolaka Utara sebagai daerah yang maju dan mandiri melalui upaya percepatan pertumbuhan pembangunan, dengan menempatkan pembangunan ekonomi sebagai fokus utama.

Pesatnya pembangunan di segala bidang yang dilakukan oleh pemerintah Kabupaten Kolaka Utara telah dapat menjangkau seluruh pelosok pedesaan. Hal ini ditandai dengan semakin tingginya tingkat kesejahteraan masyarakat Kabupaten Kolaka Utara hingga ke pelosok pedesaan. Indikator pertumbuhan ini dilihat dengan semakin tingginya angka imigrasi penduduk ke Kabupaten Kolaka Utara. Sungguh pun demikian pergerakan perekonomian masyarakat Kabupaten Kolaka Utara sangat dinamis dan pluktuatif. Terjadinya pertumbuhan yang sangat berpluktuasi ini dapat diartikan bahwa pertumbuhan lapangan kerja yang terjadi bukan pada sektor formal, melainkan sektor non formal. Untuk memacu pertumbuhan ekonomi yang lebih statis, maka ekonomi sektor formal perlu didorong. Karena itu kebijakan pemerintah dalam hal ini diarahkan untuk mendorong tumbuhnya sektor industri khususnya industri pendukung sektor pertanian dan industri pengelolaan tambang.

Penulis tertarik meneliti terhadap persoalan di atas dengan harapan hasil penelitian dapat memberikan hasil dan berguna bagi Kabupaten Kolaka Utara.

\section{B. KERANGKA TEORIS}

Pembahasan tentang kebijakan publik, aktor mempunyai posisi yang sangat strategis bersama-sama dengan faktor kelembagaan (institusi) kebijakan itu sendiri. Interaksi aktor dalam kelembagaan inilah yang kemudian menentukan proses perjalanan dan strategi yang dilakukan oleh komunitas kebijakan dalam makna yang lebih luas. Pada prinsipnya aktor kebijakan adalah mereka yang selalu dan harus terlibat dalam setiap proses analisis kebijakan publik, baik berfungsi sebagai perumus maupun kelompok penekan yang senantiasa aktif dan proaktif di dalam melakukan interaksi dan interelasi di dalam konteks analisis kebijakan publik. (Howlett dan Ramesh, Weimer dan Vining dalam Madani (2011:37).

Secara lebih makro konsep Anderson dalam Madani (2011:37) adalah diungkap bahwa aktor kebijakan meliputi aktor internal birokrasi dan aktor eksternal yang selalu mempunyai konsern terhadap kebijakan. Mereka dapat terdiri dari aktor individu maupun kelompok yang turut serta dalam setiap perbincangan dan perdebatan tentang kebijakan publik. Dengan demikian, dapat dipahami bahwa makna aktor dalam katannya dengan kebijakan publik selalu terkait dengan pelaku dan penentu terhadap suatu kebijakan yang berinteraksi dan melakukan interrelasi di dalam setiap tahapan proses kebijakan publik. Anderson menegaskan bahwa proses bargaining dapat terjadi dalam tiga bentuknya yaitu negosiasi (negotiation), salaing memberi dan menerima (take and give) dan kompromi (compromise). Sesungguhnya penjelasan bargaining berakar pada istilah bahwa jika terdapat dua atau lebih aktor atau kelompok 
aktor yang masing-masing memiliki kewenangan dan posisi tertentu tetapi dapat melakukan penyesuaian (sharing) yang di harapkan dapat terbangun dalam sistem pembahasannya. Dengan demikian negosiasi menjadi langkah awal untuk membentuk opini dan mengarahkan aktor untuk melakukan langkah negosiasi. Setelah proses negosiasi antaraktor terjadi dalam posisi yang berbeda di antara aktor, maka prinsip saling memberikan dan menerima kemudian mewarnai proses pengambilan kebijakan yang di bahas dalam forum aktor yang terlibat. Pada akhirnya proses itu akan berujung pada proses kompromistik dimana masing-masing aktor saling melakukan penyesuaian dengan konsep atau ide aktor yang lainnya sehingga dapat di putuskan kebijakannya. Hal ini dalam pandangan Anderson di anggap sebagai bentuk bargaining dengan tipe yang ekspleisit.

Perumusan kebijakan dalam prakteknya akan melibatkan berbagai aktor, baik yang berasal dari aktor negara maupun aktor non negara atau yang disebut oleh Anderson (2006:46-67) sebagai pembuat kebijakan resmi (official policy-makers) dan peserta non pemerintahan (nongovernmental participants). Pembuat kebijakan resmi adalah mereka yang memiliki kewenangan legal untuk terlibat dalam perumusan kebijakan publik. Mereka ini menurut Anderson (2006:46-57) terdiri atas legislatif, eksekutif, badan administratif, serta pengadilan. Legislatif merujuk kepada anggota kongres/dewan yang seringkali dibantu oleh para staffnya. Adapun eksekutif merujuk kepada Presiden dan jajaran kabinetnya. Sementara itu, badan administratif menurut Anderson merujuk kepada lembagalembaga pelaksana kebijakan. Dalam konteks Amerika, aktor ini merujuk kepada sejumlah badan seperti misalnya Badan Penerbangan Federal (Federal Aviation Agency) serta Badan Perlindungan Lingkungan (Environmental Protection Agency). Dipihak lain menurut Anderson, Pengadilan juga merupakan aktor yang memainkan peran besar dalam perumusan kebijakan melalui kewenangan mereka untuk mereview kebijakan serta penafsiran mereka terhadap undang-undang dasar. Dengan kewenangan ini, keputusan pengadilan bisa mempengaruhi isi dan bentuk dari sebuah kebijakan publik.

Pada pihak lain Thomas Dye dalam Subarsono (2005:2) merumuskan kebijakan publik sebagai semua tindakan yang dilakukan oleh pemerintah atau apapun pilihan pemerintah untuk melakukan atau tidak melakukan (publik policy is whatever governments choose to do or not to do). Konsep tersebut sangat luas karena kebijakan publik mencakup suatu yang tidak dilakukan oleh pemerintah di samping yang dilakukan oleh pemerintah ketika pemerintah mengalami suatu masalah publik. Sebagai contoh, ketika pemerintah mengetahui bahwa ada jalan raya yang rusak dan dia tidak membuat kebijakan untuk memperbaikinya, berarti pemerintah sudah mengambil kebijakan. Definisi kebijakan publik dari Thomas Dye tersebut mengandung makna bahwa (1) kebijakan publik tersebut di buat oleh badan pemerintah, bukan organisasi swasta; (2) kebijakan publik menyangkup pilihan yang harus dilakukan atau tidak dilakukan oleh badan pemerintah. Kebijakan pemerintah untuk tidak membuat kebijakan baru atau tetap pada status quo, misalnya tidak menunaikan pajak adalah sebuah kebijakan publik.

Menyangkut kebijakan publik ini, Anderson (2006:10-17) membaginya kedalam empat kategori dari kebijakan publik, yakni: kebijakan substantif dan prosedural; kebijakan distributif, pengaturan, pengaturan sendiri, dan redistribusi; kebijakan material dan simbolik; serta kebijakan yang melibatkan barang kolektif atau barang privat. Kategori kebijakan yang terakhir menurut Anderson adalah kebijakan yang melibatkan penyediaan baik arang-barang kolektif maupun barangbarang privat. Barang-barang kolektif adalah barang-barang yang harus disediakan kepada semua orang, sementara barang privat adalah barang-barang yang dikonsumsi oleh individu tertentu saja. Contoh barang kolektif adalah pertahanan, sementara barang privat adalah pengumpulan sampah.

Proses pembuatan sebuah kebijakan publik melibatkan berbagai aktivitas yang kompleks. Pemahaman terhadap proses 
pembuatan kebijakan oleh para ahli dipandang penting dalam upaya melakukan penilaian terhadap sebuah kebijakan publik. tahapan perumusan kebijakan merupakan tahap kritis dari sebuah proses kebijakan. Hal ini terkait dengan proses pemilihan alternatif kebijakan oleh pembuat kebijakan yang biasanya mempertimbangkan besaran pengaruh langsung yang dapat dihasilkan dari pilihan alternatif utama tersebut. Proses ini biasanya akan mengekspresikan dan mengalokasikan kekuatan dan tarik menarik diantara berbagai kepentingan sosial, politik dan ekonomi.

Menurut Sidney dalam Fischer, Miller and Sidney (2007:79), tahap perumusan kebijakan melibatkan aktivitas identifikasi dan atau merajut seperangkat alternatif kebijakan untuk mengatasi sebuah permasalahan; serta mempersempit seperangkat solusi tersebut sebagai persiapan dalam penentuan kebijakan akhir.

Selanjutnya, menurut Sidney alternatif akan melibatkan proses identifikasi terhadap berbagai pendekatan untuk menyelesaikan masalah serta kemudian mengidentifikasi dan mendesain seperangkat perangkat kebijakan spesifik yang dapat mewakili setiap pendekatan. Tahap perumusan juga melibatkan proses penyusunan draft peraturan untuk setiap alternative yang isinya mendeskripsikan diantaranya mengenai sanksi, hibah, larangan, hak serta mengartikulasikan kepada siapa atau kepada apa ketentuan tersebut akan berlaku dan memiliki dampak.

Berdasarkan berbagai definisi para ahli kebijakan publik, bahwa kebijakan publik adalah kebijakan-kebijakan yang dibuat oleh pemerintah sebagai pembuat kebijakan untuk mencapai tujuan-tujuan tertentu di masyarakat di mana dalam penyusunannya melalui berbagai tahapan. Tahap-tahap pembuatan kebijakan publik menurut William Dunn (1998:24) adalah sebagai berikut: Penyusunan Agenda, Formulasi kebijakan, Adopsi Kebijakan, Implementasi Kebijakandan Penilaian/ Evaluasi Kebijakan.

Pertambangan mempunyai beberapa karakteristik, yaitu tidak dapat diperbarui (non-reneweble), mempunyai resiko relatif lebih tinggi, dan pengusahaannya mempunyai dampak lingkungan baik fisik maupun sosial yang relatif lebih tinggi dibandingkan pengusahaan komoditi lain pada umumnya. Pada dasarnya, karena sifatnya yang tidak dapat di perbaharui tersebut pengusaha pertambangan selalu mencari cadangan terbukti (proven reserves) baru.

Hal lain yang masih dipertentangkan adalah berapa bagian keuntungan pemerintah dari usaha pertambangan tersebut. Penjelasan dari pemerintah mengenai kontrak emas dan pertambangan umum lainnya (tertuma mengenai pembangian keuntungannya) yang berlaku di Indonesia, perbandingan kontrak tersebut dengan yang berlaku Negara-negara lain, keuntungan (rate of return) rata-rata usaha tersebut di Indonesia perlu di berikan untuk mengetahui apakah keuntungan pemerintah tersebut memadai atau tidak. Mungkin perlu juga di pikirkan kebijakan pajak yang berbeda untuk ukuran cadangan yang berbeda karena keuntungannya pun berbeda. Perlu dicatat bahwa beberapa Negara memperlakukan kontrak pertambangan yang berbeda bagi BUMN, swasta nasional, dan swasta asing. Akan lebih baik lagi apabila imformasi tersebut di sertai dengan biaya pengusahaan pertambangan untuk berbagai kondisi tambang terutama yang terjadi terhadap pengelolaan pertambangan di Kabupaten Kolaka Utara.

Dasar kebijakan publik di bidang pertambangan Kabupaten Kolaka Utara adalah Undang-Undang 1945 Pasal 33 Ayat (3) yang menyatakan bahwa bumi dan air dan kekayaan alam yang terkandung di dalamnya dikuasi oleh Negara dan digunakan sebesar-besarnya untuk kemakmuran rakyat. Dalam pelaksana-annya mungkin dapat dipertimbangkan hal-hal berikut ini:

1. Kita baru akan mengundang perusahaan asing apabila bangsa Indonesia tidak berani mengambil resiko atau tidak menguasai tekhnologi untuk bidang pertambangan tersebut. Alasannya, apabila dana tersebut dikeluarkan oleh pengusaha asing, tentunya dana tersebut akan kembali kenegara dimana pengusaha tersebut berasal, tetapi akan lebih menguntungkan apabila dikerjakan oleh pengusaha Lokal. 
2. Apabila resikonya tidak besar, serta teknoginya di kuasai dan permasalahannya hanya modal, maka dana dapat di kumpulkan melalui beberapa cara, yaitu sebagai berikut :

a). Sebagian pendapatan pemerintah dari sektor pertambangan umum yang sudah memberikan keuntungan banyak (misal: batu bara). Pendapatan tersebut dapat di gunakan untuk ekplorasi dan investasi pada sektor-sektor pertambangan lainnya. Hal yang sama dapat di perlakukan untuk migas, sehingga sebagian pendapatan pemerintah dari migas dapat digunakan untuk eksplorasi dan investasi untuk energy lain yang lebih bersih lingkungan, seperti pasan bumi dan tenaga air. Sebagai perbandingan, pada sektor kehutanan terdapat dana reboisasi.

b). BUMN yang terkait dapat mengumpulakan dana dari saham masyarakat yang sebesarnya tergantung pada kepercayaan masyarakat pada hasil usaha di bidang tersebut.

c). Swasta nasional yang berminat berusaha dibidang tersebut (baik sendiri maupun konsorsium) diikutsertakan dalam usaha tersebut.

d). Apabila sumber di atas dana tidak cukup maka baru diusahakan modal asing

3. Aspek lingkungan baik fisik maupun sosial harus di pertibangkan dalam setiap kontrak pertambangan dan pengusaha pertambangan harus menyediakan biaya untuk mengatasi permasalahan lingkungan tersebut.

4. Apabila kontrak bagi hasil untuk pertambangan umum lebih menguntungkan dibandingkan kontrak karya (dengan pengertian juga tidak kontraktor jera), maka tentunya yang lebih menguntungkan masyarakat perlu di berlakukan.

Tiga tahun belakangan ini, pemerintah pemerintah berusaha mempersiapkan Undang-Undang baru mengenai sektor pertambangan karena ketidakjelasan kerangka hukumnya. Undang-Undang baru ini membahas peraturan perizinan baru yang disesuaikan dengan Undang-Undang No. 32 tahun 2004 tentang Pemerintahan Daerah mengenai desentralisasi. Akan tetapi, rancangan tersebut belum dapat disesuaikan dan diserahkan ke parlemen, sehingga terdapat kekosongan peraturan perundang-undangan, yang saat ini diambil alih oleh berbagai peraturan baik dari pemerintah pusat maupun pemerintah provinsi dan daerah tingkat dua. Akibatnya, muncul ketidakpastian dan resiko. Peraturan di tingkat daerah ini menyebabkan munculnya ketidakpastian dan meningkatkan resiko, terutama berkaitan dengan interprestasi dan implementasi berbagai peraturan tersebut. Hal ini membuka kemungkinan korupsi dan menyebabkan lemahnya penegakan hukum.

\section{Mengisi kekosongan hukum}

Masalah inkonsistensi aturan perundangan bukanlah masalah yang hanya terjadi di sektor pertambangan. Pada sektor ini permasalahan tersebut dapat dipecahkan dengan mengeluarkan sebuah UndangUndang baru mengenai pertambangan. Para investor hanya akan bersedia menanamkan modal secara besar-besaran, jika terdapat kepastian mengenai masa operasi mereka. Hal ini membutuhkan peraturan local yang konsisten, dapat diprediksi, tidak tumpang tindih dan di berikan secara eksklusif. Selain itu, proses Undang-Undang tersebut harus menjelaskan proses penutupan dan rehabilitas pertambangan, dan tidak adanya perlakuan yang berbeda antara investor asing dan investor domestik.

\section{Peraturan perlindungan lungkungan hidup tidak mencukupi}

Investor yang serius menginginkan peraturan yang jelas dan di jalankan secara konsisten di seluruh sektor. Investor yang serius menginginkan adanya kebijakan lingkungan hidup, keselamatan, dan kesehatan kerja yang jelas, konsisten, dan realistis. Ini tercermin dalam berbagai peraturan yang dapat di terapkan. Tidak adanya persyaratan lingkungan hidup yang kelas membuat para investor sulit mendapatkan dana di pasar modal internasional. Hal tersebut juga akan membuat investor harus menerima kritik 
karena di anggap tidak menjalankan tanggung jawab dengan baik. Kenerja yang uruk dari aktivitas penambangan kecil dan illegal akan membuat seluruh sektor mendapat kecaman.

\section{METODE PENELITIAN}

Penelitian ini mengambil lokasi pada kantor Pemerintah Daerah dan Dewan Perwakilan Rakyat Daerah (DPRD) dengan alasan bahwa untuk mengetahui bagaimana interaksi aktor dalam perumusan kebijakan pengelolaan pertambangan di Kabupaten Kolaka Utara. Tipe penelitian yang digunakan adalah tipe penelitian Deskriptif Kuantitatif yang dikombinasi dengan data Kualitatif, yaitu tipe penelitian yang berusaha untuk menggambarkan secara jelas tentang interaksi aktor dalam perumusan kebijakan pengelolaan pertambangan. Dasar penelitian yang dilakukan adalah survey yaitu penelitian dengan mengumpulkan dan menganalisis suatu peristiwa atau proses tertentu dengan memilih data atau menemukan ruang lingkup tertentu sebagai sampel yang dianggap representatif. Mengingat fokus dari penelitian ini adalah interaksi aktor dalam kebijakan pengelolaan pertambangan di Kabupaten Kolaka Utara, maka yang menjadi populasi dari penelitian ini adalah DPRD (Dewan Perwakilan Rakyat Daerah), Badan Perencanaan pembangunan daerah (bappeda), Dinas Pertambangan, Energy dan Sumber Daya Mineral dan Badan Lingkungan Hidup. Teknik penarikan sampel dalam penelitian ini dilakukan secara purvosive sampling bertujuan untuk memilih responden dan informan secara sengaja yang dianggap tahu pasti tentang Interaksi Aktor dalam perumusan kebijakan pengelolaan pertambangan di Kabupaten Kolaka Utara yaitu sebanyak 20 orang. Responden: Komisi III DPRD Kolaka Utara sebanyak 5 Orang, Badan Perencanaan Pembanguna Daerah (Bappeda) sebanyak 5 Orang, Dinas pertambangan, energi dan sumber daya mineral sebanyak 5 Orang dan Tokoh masyarakat sebanyak 5 Orang. Informan: Bupati Kolaka Utara, Ketua DPRD Kabupaten Kolaka Utara, Kepala Badan Peren- canaan Pembangunan Daerah (Bappeda), Kepala Dinas Pertambangan, Energy dan Sumber Daya Mineral, Sekretaris Dewan, Tokoh Masyarakat dan LSM. Teknik Pengumpulan Data dilakukan dengan : Observasi, Wawancara dan Kuesioner. teknik analisis data yang penulis gunakan dalam mengelola data adalah teknis analisis deskiptif Kuantitatif dari data hasil observasi, wawancara dan kuesioner. Setelah data dikumpulkan selanjutnya dianalisis data melalui tabel frekwensi dan dari data wawancara.

\section{Interaksi Aktor dalam Perumusan \\ Kebijakan Pengelolaan Pertambangan}

Hubungan antara pemerintah daerah dan DPRD merupakan hubungan kerja yang kedudukannya setara dan bersifat kemitraan. Kedudukan yang setara bermakna bahwa diantara lembaga pemerintahan daerah itu memiliki kedudukan yang sama dan sejajar, artinya tidak saling membawahi. Melihat interaksi antara aktor dalam perumusan kebijakan pengelolaan pertambangan di kabupaten kolaka utara di lihat dari tiga cara yaitu pola kerja sama (bargaining), model persuasif (persuasion) dan pengarahan (commanding).

\section{Pola Kerja Sama (Bargaining)}

\section{Tabel 1 :}

Tanggapan responden tentang hubungan yang terjalin antara DPRD dan Pemerintah Daerah.

\begin{tabular}{|l|l|c|r|}
\hline No. & Kategori Jawaban & Frekuensi & Persentase (\%) \\
\hline 1. & Sangat Terjalin & 7 & $35 \%$ \\
\hline 2. & Terjalin & 11 & $55 \%$ \\
\hline 3. & Kurang Terjalin & 2 & $10 \%$ \\
\hline 4. & Tidak Terjalin & - & $0 \%$ \\
\hline \multicolumn{2}{|l|}{ Jumlah } & 20 & $100 \%$ \\
\hline
\end{tabular}

Sumber: Hasil olahan kuesioner 2012

Dari data diatas dapat disimpulkan bahwa hubungan yang terjalin antara DPRD dan Pemerintah Daerah yaitu sebanyak 7 responden (35\%) yang menyatakan sangat terjalin, 11 responden (55\%) yang menya- 
takan terjalin dan 2 responden (10\%) yang menyatakan kurang terjalin. Hal ini menunjukkan bahwa banyaknya responden yang mengatakan bahwa hubungan yang terjalin antara DPRD dan Pemerintah Daerah sudah terjalin.

"Hubungan antara Pemerintah Daerah dan DPRD di lihat dari relitasnya bahwasanya memang pernah tidak sejalan dan ini dikatakan tidak baik, tetapi hanya pada saat Pilkada berlangsung, tetapi setelah Pilkada berakhir hubungan keduanya pun kian membaik". (Wawancara, S, kamis- 07-2012)

Tabel 2:

Tanggapan Responden tentang keberhasilan pola kerja sama yang di lakukan oleh Pemerintah Daerah dengan

DPRD dalam merumuskan kebijakan pengelolaan pertambangan tentang persoalaan hak kepemilikan tanah warga yang masuk dalam area pertambangan. kelompok adalah adanya kelompok aktor yang menyebabkan aktor lain mengubah keputusan mereka ini bisa di lihat dari adanya negosiasi dan kompromi yang di lakukan oleh aktor perumus kebijakan, baik ke arah yang lebih teliti, atau lebih mengandung resiko dengan mengumpulkan pendapat kelompok aktor sampai tahap penentuan suatu kebijakan.

Tabel 3 :

Tanggapan responden tentang ketepatan negosiasi yang di lakukukan antara Pemerintah Daerah dan DPRD dalam perumusan kebijakan pengelolaan pertambangan.
Sumber: Hasil olahan kuesioner 2012

Dari hasil data diatas dapat disimpulkan bahwa tanggapan responden tentang nego-

kan pengelolaan pertambangan, 2 responden (10\%) mengatakan sangat tepat, 11 responden (55\%) mengatakan tepat, 6 responden (30\%) mengatakan kurang tepat, dan 1 responden (5\%) mengatakan tidak tepat. Hal ini menunjukkan bahwa banyaknya responden yang mengatakan tepat, maka negosiasi yang di lakukukan antara Pemerintah Daerah dan DPRD dalam perumusan kebijakan pengelolaan pertambangan sudah tepat. Hal ini senada dengan yang dikatakan, bahwa :

"Perumusan suatu kebijakan memang butuh proses dan waktu yang tidak sedikit, moment ini yang digunakan oleh pemerintah untuk bernegosiasi dalam menetapkan kebijakan yang tepat. (Wawancara, S, Rabu07-2012).

Tabel 4 :

Tanggapan responden tentang persetujuan Pemerintah Daerah dan DPRD dalam mengkompromikan permasalahan yang terjadi tanpa mengabaikan kepentingan masyarakat. 
Tabel 4:

Tanggapan responden tentang persetujuan Pemerintah Daerah dan DPRD dalam mengkompromikan permasalahan yang terjadi tampa mengabaikan kepentingan masyarakat.

Sumber: Hasil olahan kuesioner 2012

Dari data diatas dapat disimpulkan bahwa tanggapan responden tentang persetujuan Pemerintah Daerah dan DPRD dalam mengkompromikan permasalahan yang terjadi tampa mengabaikan kepentingan masyarakat. Adapun yang menyatakan sangat setuju yaitu 3 responden (15\%), 11 responden (55\%) yang menyatakan setuju, 4 responden (20\%) yang menyatakan kurang setuju, dan 2 responden (10\%) yang menyatakan tidak setuju. Hal ini menunjukkan bahwa adanya responden yang mengatakan bahwa persetujuan Pemerintah Daerah dan DPRD dalam mengkompromikan permasalahan yang terjadi tampa mengabaikan kepentingan masyarakat ini kurang setuju dan hal ini dapat mengurangi kepercayaan masyarakat terhadap pemerintah dalam fungsinya untuk mensejahtrakan masyarakat. Sebagaimana yang dikemukakan oleh salah seorang informan dalam wawancara penulis bahwa :

"Banyaknya permasalahan yang terjadi terutama di daerah yang lokasinya dekat tambang terutama masyarakat yang tanahnya masuk dalam area penambangan ini dalam hal ganti rugi atas tanah yang dimilikinya yang di olah oleh pihak penambang belum dapat terselesaikan." (Wawancara, A. Kamis, 072012).

\section{Pengarahan (Commanding)}

Proses pengambilan kebijakan publik dengan menempatkan adanya pola hierarki yang berlaku antara aktor satu dengan aktor yang lain disebut sebagai pengarahan (com- manding). Pola hubungan dan interaksi antara aktor pada model ini adalah berkaitan dengan pola perumusan kebijakan yang sangat struktural, dimana satu kelompok aktor menjadi superordinat dan kelompok yang lain tentu saja menjadi subordinat. Tipe pengambilan kebijakan menempatkan posisi ini mirip dengan kewenangan yang dimiliki oleh lembaga perumus pengelolaan sumber daya alam daerah dalam bentuk kebijakan.

Tabel 5 :

Tanggapan responden tentang tahap-tahap proses perumusan kebijakan pengelolaan pertambangan yang di lakukan oleh aktor perumus kebijakan.

Sumber: Hasil olahan kuesioner 2012

Dari data diatas dapat disimpulkan bahwa tanggapan responden tentang tahap-tahap proses perumusan kebijakan pengelolaan pertambangan yang di lakukan oleh aktor perumus kebijakan. Adapun tanggapan responden yaitu 3 responden (15\%) yang menyatakan sangat bertahap, 14 responden (70\%) yang menyatakan bertahap, 2 responden (10\%) yang menyatakan kurang bertahap, dan 1 responden (5\%) yang menyatakan tidak bertahap. Hal ini menunjukkan bahwa masih adanya responden yang mengatakan kurang bertahap bahkan tidak bertahap maka pengarahan yang terjalin antara aktor satu dengan yang lain dikatakan kurang efektif.

Faktor-faktor Pendukung dan Penghambat Interaksi Aktor dalam Perumusan

Kebijakan Pengelolaan Pertambangan di Kabupaten Kolaka Utara.

\section{Pengarahan (Commanding)}

Hubungan dinamis yang tercipta antara kebijakan dan lingkungan sebagai wujud dari kebijakan, dalam hal ini terutama hubungan atau interaksi antara aktor perumus kebijakan dan yang menetapkan kebijakan. 
Tabel 6 :

Tanggapan responden tentang keharmonisan komunikasi yang terjalin antara aktor kebijakan pengelolaan pertambangan di kabupaten kolaka utara. \begin{tabular}{l|l}
\multicolumn{2}{c}{ ini menunjukkan bahwa keharmonisan } \\
lemmunikasi yang terijalin antara aktor peru-
\end{tabular} mus kebijakan pengelolazn pertambangan

Sumber: Hasil olahan kuesioner 2012

Dari data diatas dapat disimpulkan bahwa tanggapan responden tentang keharmonisan komunikasi yang terjalin antara aktor kebijakan dalam perumuan kebijakan pengelolaan pertambangan di kabupaten kolaka utara. Adapuntanggapan responden yaitu 4 responden $(20 \%)$ yang menyatakan sangat harmonis, 14 responden (70\%) yang menyatakan harmonis, 2 responden $(20 \%)$ yang menyatakan kurang harmonis, dan tidak ada responden (10\%) yang menyatakan tidak harmonis. Hal sanisgat baik dan ini mentunjang keberhasilan

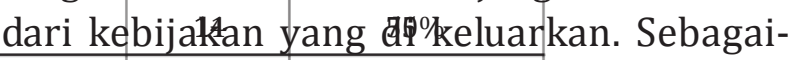
Kurang hailitroana yang adikemukakrax oleh salah seorang Tidak hailmdinforman dąlam wawaægara penulis bahwa : Jumlah "Keharmonisan kobomikasi yang terjalin antara DPRD dan Penda dalam perumusan kebijakan ini tidak lain baaiman pemerinrah daerah kabupaten kolaka utara lebih mementingkan apa yang di butuhkan demi menunjang pembangunan daerah dan apa yang di butuh kan masyarakat, serta tugas dan fungsi yang dipahami Oleh kedua lembaga tersebu." (Wawancara, A. Kamis, 07-2012).

Komunikasi yang harmonis akan menciptakan hubungan kerja yang juga harmonis. Komunikasi Legislatif dan Eksekutif daerah yang terganggu akan berdampak kurang baik pada kinerja kedua lembaga tersebut.

\section{Sumber Daya Pelaksana}

Peningkatan sumber daya masyarakat yang sejalan dengan ketersedian lapangan kerja. Melalui sumber dayanya diharapkan perusahaan dapat menciptakan lapangan kerja bagi masyarakat. Peningkatan sumber daya manusia di dinas pertambangan sangat penting mengingat target yang ingin dicapai dalam pelaksanaan program pembangunan daerah kabupaten kolaka utara.

Tabel 7:

Tanggapan responden tentang Peningkatan sumber daya masyarakat yang sejalan dengan ketersedian lapangan kerja.

Sumber: Hasil olahan kuesioner 2012

Berdasarkan data di atas dapat disimpulkan bahwa tanggapan responden tentang Peningkatan sumber daya masyarakat yang sejalan dengan ketersedian lapangan kerja adalah $25 \%$ responden mengatakan sangat baik, sedangkan $55 \%$ responden yang mengatakan baik, sedangkan yang menyatakan kurang baik hanya $15 \%$ dan responden yang mengatakan tidak baik sebanyak $5 \%$. Hal ini dapat disimpulkan bahwa banyaknya responden yang mengatakan sangat baik maka Peningkatan sumber daya masyarakat yang sejalan dengan ketersedian lapangan kerja dapat dikatakan sudah sangat baik. Hal ini senada dengan hail wawancara, bahwa :

"Pemerintah daerah berusaha meningkatkan sumber daya manusia untuk peningkatan kesejahteraan masyarakat. Tentu hal ini didukung dengan usaha peningkatan lapangan pekerjaan yang luas bagi masyarakat dan ini di lihat dari banyak nya perusahaan pertambangan yang ada di Kolaka Utara." (wawancara, H M, Selasa, Rabu 07-2012)

Ketersediaan lapangan kerja bagi masyarakat ini tidak terlepas dari bagaimana peran pemerintah daerah dalam program pembangunan di sektor pertambangan. Program pemerintah ini dilakukan dalam semua tahap, mulai dari perencanaan, pelaksanaan, pemantauan dan evaluasi dari semua kebija- 
kan dan program pembangunan. Peningkatan sumber daya manusia/pelaksana menjadi begitu penting dalam pelaksanaan program pembangunan terutama di sektor pertambangan.

Faktor penghambat interaksi aktor dalam perumusan kebijakan pengelolaan pertambangan di kabupaten kolaka utara.

Faktor penghambat interaksi aktor dalam perumusan kebijakan pengelolaan pertambangan di kabupaten kolaka utara.

\section{Komitmen}

Komitmen masing-masing aktor dalam mewujudkan perumusan kebijakan publik, khususnya aktor pemerintah yang selama ini merasa mendominasi proses perumusan kebijakan tersebut. Kedua, mekanisme pelaksanaan kegiatan khususnya yang bersifat proyek, terkendala oleh berbagai keterbatasan seperti waktu, dana, mekanisme pengelolaan dan tata aturan yang sangat teknis dan mekanistis.

Tabel 8 :

Tanggapan responden tentang komitmen pemerintah dalam mewujudkan kebijakan pengelolaan pertambangan yang efektif dan efisien.

Sumber: Hasil olahan kuesioner 2012

Pada tabel di atas, dapat dilihat penilaian responden tentang komitmen pemerintah dalam mewujudkan kebijakan pengelolaan pertambangan yang efektif dan efisian, yang mana menunjukkan bahwa 2 respoden menilai dengan persentase $10 \%$ yang menyatakan komitmen, sebanyak 15 orang atau 15\% yang menyatakan kurang komitmen, dan ada 3 orang atau $15 \%$ yang menyatakan Tidak komitmen. Maka dapat dikatakan bahwa komitmen pemerintah tidak baik dalam mewujudkan kebijakan pengelolaan pertambangan.
Upaya untuk mewujudkan produk kebijakan yang efektif dan efisien pemerintah kabupaten kolaka utara tidak seharus melanggar komitmennya dalam meruskan kebijakan yang di keluarkannya, karena dengan demikian hal ini dapat berdampak pada kurang kepercayaan publik terhadap kinerja pemerintah itu sendiri. Hal ini dapat mempengaruhi keterlambatannya proses kinerja pemerintah dalam pembangunan daerah.

\section{Struktur Birokrasi}

Masalah yang nampak adalah kapasitas birokrasi dari aktor perumus kebijakan belum mampu dalam melakukan analisis permasalahan yang terjadi dan belum dapat mengintegrasikan isu yang ada. Dominasi dari para pemangku kebijakan masih dirasakan begitu kuat dalam perumusan kebijakan pengelolaan pertambangan.

Tabel 9:

Tanggapan responden tentang kapasitas birokrasi dalam perumusan kebijakan pengelolaan pertambangan.

Sumber: Hasil olahan kuesioner 2012

Berdasarkan pada table di atas, dapat disimpulkan bahwa tanggapan responden tentang kapasitas birokrasi dalam perumusan kebijakan pengelolaan pertambangan dengan persentase $10 \%$ yaitu 2 responden mengatakan sangat berkapasitas, 3 responden (15\%) mengatakan berkapasitas, 12 responden (60\%) mengatakan kurang berkapasitas dan 3 responden (15\%) mengatakan tidak berkapasitas. Maka dapat dikatakan bahwa dengan persentase $15 \%$ menyatakan berkapasitas dinilai tidak mencapai memenuhi harapan. Hal yang ini juga dikatakan oleh informan kami dalam wawancara, bahwa :

"Kebijakan yang dibuat pemerintah daerah terkesan dipaksakan, dengan kondisi dan situasi dari dinas-dinas pemerintahan." 
Upaya peran aktor perumus kebijakan, dilakukan peningkatan dalam berbagai bidang termasuk pemerintahan. Dalam upaya ini, diperlukan suatu reformasi birokrasi yang mengarah pada pencapaian kesetaraan masyarakat. Peningkatan profesionalisme aparat dan kapasitasnya dalam birokrasi.

\section{E. KESIMPULAN}

Dilihat dari segi efektifitas serta efesiensinya cukup padu dalam setiap adanya kebijakan serta jika ada kebijakan baru yang memungkinkan untuk dikelola bersama khususnya kebijakan pengelolaan pertambangan. Kualitas dari kebijakan sangat dipengaruhi oleh intensitas interaksi antar aktor untuk saling memahami kepentingan masing-masing pihak sehingga formulasi kebijakan publik merupakan hasil negosiasi dari antar aktor yang terlibat dalam proses perumusan kebijakan. Ini semua dapat terjadi sebab Mekanisme interaksi antar aktor dalam perumusan kebijakan mempertemukan kepentingan masing-masing aktor, berlangsung sepanjang proses perumusan dan pelaksanaan kebijakan publik. Mekanisme interaksi intensif inilah yang menyebabkan peluang-peluang untuk saling mengakomodasi kepentingan masing-masing aktor menjadi lebih mudah terjadi.

Faktor pendukung interaksi aktor dam perumusan kebijakan pengelolaan pertambangan di Kabupaten Kolaka Utara ialah: komunikasi, hubungan dinamis yang tercipta antara kebijakan dan lingkungan sebagai wujud dari kebijakan, Komunikasi yang harmonis akan menciptakan hubungan kerja yang juga harmonis. Komunikasi Legislatif dan Eksekutif daerah yang terganggu akan berdampak kurang baik pada kinerja kedua lembaga tersebut. Sumber daya pelaksana, Peningkatan sumber daya masyarakat yang sejalan dengan ketersedian lapangan kerja. Faktor penghambat interaksi aktor dalam perumusan kebijakan pengelolaan pertambangan di kabupaten kolaka utara. Komitmen, upaya untuk mewujudkan produk kebijakan yang efektif dan efisien pemerintah kabupaten kolaka utara tidak seharus melanggar komitmennya dalam meruskan kebijakan yang di keluarkannya, karena dengan demikian hal ini dapat berdampak pada kurang kepercayaan publik terhadap kinerja pemerintah itu sendiri. Hal ini dapat mempengaruhi keterlambatannya proses kinerja pemerintah dalam pembangunan daerah. Struktur birokrasi, upaya peran aktor perumus kebijakan, dilakukan peningkatan dalam berbagai bidang diperlukan suatu reformasi birokrasi yang mengarah pada pencapaian kesetaraan masyarakat. Peningkatan profesionalisme aparat dan kapasitasnya dalam birokrasi.

\section{DAFTAR PUSTAKA}

Abidin, S. Zaenal, 2004. Kebijakan Publik. Jakarta : Pancar Siwah,

Agustino, Leo. 2006. Dasar-Dasar Kebijakan Publik. Bandung : Alfabeta.

Anderson, James E, 2006, Public Policy Making: An Introduction, Boston: Houghton Mifflin Company.

Anderson, James E, 1984. Public Policy-Making, Thirds Edition, Holt, Rinehart and Winston, New York Prees.

Danim, Sudarman. 2005. Pengantar Studi Penelitian Kebijakan. Jakarta : Sinar Grafika.

Edward III, George C,1980, Implementing Public Policy, Washington DC: Congressional Quarterly Press.

Fischer, Frank, Gerald J. Miller and Mara S. Sidney (Eds.). 2007. Handbook of Public Policy Analysis: Theory, Politics and Methods, Boca Raton: CRC Press.

Hill, Michael \& Peter Hupe , 2006, Implementing Public Policy, London: Sage.

Jones, Carles O. 1994. Pengantar Kebijakan Publik, Jakarta : Rajawali Press 
Madani, Muhlis. 2011. Dimensi Interaksi Aktor Dalam Proses Perumusan Kebijakan Publik, Yogyakarta : Graha Ilmu

Nugroho D, Riant, 2003, Kebijakan Publik, Formulasi, Implementasi dan Evaluasi. Jakarta : Elex Media Komputindo.

Prasetyo, Budi. 2010. "Orientasi Aktor dalam Perumusan Kebijakan Publik" Jurnal Masyarakat dan Kebudayaan Politik Vol. III (3) Hal. 23-39

Subarsono, AG, 2005. Analisis Kebijakan Publik, Yogyakarta : Pustaka Pelajar

Sugiyono, 2010, Metode Penelitian Kuantitatif Kualitatifdan $R \& D$, CV Bandung: Alfabeta

Suryabarata Sumajdi, 1985, Metode Penelitian, Jakarta : Rajawali Press

Sutedi, Adrian. 2011. Hukum Pertambangan. Jakarta : Sinar Grafika.

Wahab, A. Solichin. 2008. Pengantar analisis kebijakan. Malang : UMM Press.

William, N Dunn, 1998. Pengantar Analisis Kebijakan Publik. Yogyakarta : Gadjah Mada University Press.

\section{Dokumen-Dokumen}

http://id.shvoong.com/social-sciences/political-science/2167357-proseskebijakan-publik/

http://id.wikipedia.org / wiki / Kebijakan_Publik

http://pengantarmanajemen.com/tahaptaha-perumusan-kebijakan-publik/

Kabupaten Kolaka Utara Dalam Angka Kolaka Utara Regency In Figures. Badan Pusat Statistik Kabupaten Kolaka Utara. 2009.

Undang-Undang Republik Indonesia Nomor 4 Tahun 2009 Tentang Petambangan Mineral dan Batu Bara.

Undang-Undang Republik Indonesia Nomor 22 tahun 1999 tentang pemerintah daerah.

Undang-Undang Republik Indonesia Nomor 32 Tahun 2004 tentang pemerintah daerah.

Profil Daerah Kabupaten Kolaka Utara, Buku Kerja) Tahun 2010. 